\title{
The Phubbing. The interference in communication within the classroom
}

\author{
El Phubbing. La interferencia en la comunicación dentro del aula de clases
}

Tirso Javier Hernández Gracia ${ }^{a}$, Danae Duana Avila ${ }^{b}$, José Francisco Hernández Gracia ${ }^{c}$

\begin{abstract}
:
Currently, the fourth industrial revolution and the advantages that it brings in relation to the use of technologies are discussed, which is also reflected in the educational field. Nowadays it is increasingly common to observe that students use the cell phone as a technological instrument that allows them to consult relevant information within the classroom, as well as perform various activities associated with the academic field. However, it has also increased the habit of misusing the mobile device by the student, by sending personal messages or entering various social pages without the authorization of their teachers and during classroom sessions, which generates interference of communication and is known as Phubbing. The objective of this research is to describe the different uses of the cell phone in a school day by university students of a technological educational institution in central Mexico. The study is quantitative, descriptive - correlational, transversal and non-experimental. A sample of 92 subjects was used. A questionnaire based on [1-3], among other authors, was applied. The main results obtained show that at least $30 \%$ of the students participating in the study use the cell phone in class for personal use, without the teacher's consent.
\end{abstract}

Keywords:

Fourth industrial revolution, Phubbing, Students, communication

\section{Resumen:}

Actualmente se habla de la cuarta revolución industrial y las ventajas que trae consigo en relación con el uso de las tecnologías, lo cual también se ve reflejado en el ámbito educativo. Hoy en día cada vez es más frecuente observar que los estudiantes utilizan el teléfono celular como un instrumento tecnológico que les permite consultar información relevante dentro del salón de clases, así como realizar diversas actividades asociadas al ámbito académico. No obstante, también se ha incrementado la costumbre de hacer un mal uso del dispositivo móvil por parte del alumno, al mandar mensajes personales o entrar a diversas páginas sociales sin la aut orización de sus maestros y durante las sesiones presenciales de clase, lo cual genera interferencia de la comunicación y es conocido como Phubbing. El objetivo de la presente investigación es describir los distintos usos del celular en un día de clases por estudiantes universitarios de una institución educativa tecnológica del centro de México. El estudio es cuantitativo, descriptivo - correlacional, transversal y no experimental. Se utilizó una muestra de 92 sujetos. Se aplicó un cuestionario basado en [1-3], entre otros autores. Los principales resultados obtenidos muestran que al menos un 30\% de los alumnos participantes en el estudio utilizan el teléfono celular en clase para su uso personal, sin consentimiento del maestro.

Palabras Clave:

Cuarta revolución industrial, Phubbing, Alumnos, comunicación

\footnotetext{
a Profesor Investigador del Instituto de Ciencias Económico Administrativas de la Universidad Autónoma del Estado de Hidalgo, programa educativo de administración, https://orcid.org/0000-0003-0425-0800,Email: thernan@uaeh.edu.mx. b Profesor Investigadordel Instituto de Ciencias Económico Administrativas de la Univ ersidad Autónoma del Estado de Hidalgo, programa educativo de administración, https://orcid.org/0000-0003-2286-2843, Email:duana@uaeh.edu.mx.

c Profesor Investigadordel Área Desarrollo de Negocios de la Universidad Tecnológica Tula Tepeji, https://orcid.org/0000-00023572-7969, Email: Josefrancisco.hernandez@uttt.edu.mx.
} 


\section{Introduction}

With the accelerated evolution of technology in all areas, including of course educational, it is necessary to form a common front among teachers, students and managers, whose purpose is to propose solutions that allow preparing the next professionals with skills, abilities, knowledge and competences to face the world of work in the so-called "fourth industrial revolution", where the intense use of the internet is gaining more and more ground in the new generations, as well as the automation of processes in companies, institutions and all kinds of public organizations, which also implies that the workforce is more specialized, having economic and social implications, since it is not possible to avoid the phenomenon that since the first industrial revolution has brought "the displacement or dismissal of workers", by the commissioning of millions of computers, robots and machines capable of performing multitasking functions faster and more accurately than the human being himself.

The purpose of the present study is not to analyze the economic and social repercussions derived from the fourth industrial revolution in terms of employment or unemployment, rather it is to address the effect that the abuse and misuse of technologies is causing in students, bringing with them a lack of sensitivity and decrease of values during the communication processes that are carried out in the classroom, mainly with the teacher, although all this has also been transferred to the family and business field, when participating in family gatherings and performing their practices and social service, respectively.

This phenomenon is known as Phubbing, which in the AngloSaxon world can be translated as non-skip, that is, to ignore a person because their attention is focused on the use of portable technology, such as cell phones or tablets. Today's student abuses the excessive use of technology at inappropriate times, that is, when he should not use them and concentrate on the communication he is receiving from the teacher in the classroom.

In this study, communication and technology are analyzed first, and then the concept of mobbing, some characteristics and associated problems are shown. Subsequently, a diagnostic test carried out with university students in a Technological University of the Center of Mexico is exposed (for reasons of confidentiality and indications of its directors, the official reason for registration of the Higher Educational Institution is omitted), as well as immediately Main findings obtained. Finally, they establish the conclusions and references.

Communication and technology

Communication is fundamental in the teaching-learning process, since it must guarantee its purpose or objective, that is, it is not enough to transmit the knowledge of a teacher to a student, but the act of understanding where both subjects participate. Every educational institution, private or public, must collaborate so that this act is fulfilled, from the pedagogical process to the curriculum of the subjects, enhancing knowledge and skills, from various scenarios and situations faced by the student, taking into account the materials and necessary technological elements [4].

It is known that currently the media have evolved widely, which becomes a challenge for education and drives to rethink the phenomenon and establish strategies by teachers, mainly, so that students use the appropriate and efficient way Information and Communication Technologies (ICT), since the level of dependence that it has generated in the human being in general is very high [5] which has also brought moments of intrusion or interference (technology) between the subjects who participate in the act of communication [6]. To ignore another person for being using a digital device, such as a Smartphone, computer, tablet, among other mobile devices that currently exist in the market is called techofertion. All of this seems like a paradox, since "one of the benefits of using ICT is that it brings us closer to those who are far away, but one of its dangers is that they take us away from those who are closest to us" [2].

It is clear that in the new emerging social context, the use of various digital mobile devices is essential, since they are part of education 4.0, which implies for the student the development of new potentials and skills for learning knowledge in various fields academics All this is plausible and necessary, since the youth of today come from generations that were born with the internet and the network, but there are also risks behind all this technological framework, which is the loss of values associated with a lack of attention that culminates in an impolite act towards those who are present.

In the classroom it is common for students, not only at the Bachelor's level, but also at the graduate level, to be distracted continuously during class, because although the teacher forbids them they see the way to hide the device and be checking their messages or in classes where they are allowed to use the tablet or computer-LAP, connect to the network to have several tabs open in the browser at the same time and thus interact in a "multitasking" way. Additionally, there are several scenarios where the constant is the same, since when a conglomerate of students is invited to attend a conference or any other academic event, under the pretext of taking photographs, they are distracted from the main objective for which they were summoned. Scientists Larry Rosen and Adam Gazzakey comment that "very possibly communication technology is simply saddening us by distracting us from essential elements of human 
communication (which is not reduced to sharing words and photos): tones of voice, looks, body language and another myriad of variables that are part of a conversation" [7]. Phubbing concept and associated problems

It is not intended to minimize the importance of virtual society, since it is recognized that institutions promote their educational offer in various modalities, in addition to the constant renewal of their classrooms and learning scenarios where the use of cutting-edge technologies is highlighted, as well as the continuing education that their teachers receive to be better prepared in the use of modern teaching materials. Nowadays a student who does not interact with his classmates and teachers through various technological devices is condemned to be an isolated or marginalized entity, with little chance of being able to adapt to today's educational world. However, abuse and misuse of the various electronic devices causes an addiction that often tends to "scratch" in exaggeration, triggering a series of negative attitudes that prevent communication between different subjects. As mentioned before, it is common for this type of situation to occur in a recurring classroom while the teacher is teaching or a team of students exposes a topic related to the subject being studied. Although there are several devices that become distracting, the one that stands out the most is the mobile phone.

In the Anglo-Saxon world this phenomenon is known as Phubbing, hence it is a term formed by two words $<<$ phone, which means telephone and snubbing, which means to despise >> [8] defines this construct as: "the act of belittling who accompanies us by paying more attention to mobile phones or other electronic devices than to his person". According to various investigations, this term appeared for the first time in Australia, more specifically in 2013, when referring to the behavior of ignoring another person during a conversation because they are operating a cell phone, which causes communication interference [9].

The structure of the Phubbing is multidimensional, since the cellular devices agglutinate in its interior various functions, that is, although the fundamental purpose is to make telephone calls between one or more people, they also offer services such as: internet, social networks ( whatsapp, facebook, emails, twitter, instagram, etc.), videogames, websites with specific purposes such as health, fashion, entertainment, among others. It is precisely that when you have access to this type of information in situations where they are not the most conducive to doing so, it is when a lack of attention or distraction is generated.

The focus of study that is given to Phubbing is the educational one, however it is important to highlight the problems that cell addiction can cause and that unfortunately there are already documented cases where this type of distractions have had a severe impact on traffic accidents, traffic accidents, couple or family problems, health effects (stress, depression, anxiety, aggressive behaviors, nervousness, anxiety, nomophobia, among others).

Nomophobia, according to [10], is: "the irrational fear of leaving home without a mobile phone ... is a very common psychological disorder, more in young people." This concept is broader, since it also refers to the feeling of feeling disconnected from the world in general. It is precisely this type of sensations that students get to feel, not only knowing that their cell phone may run out of battery during their school day, but the temptation to want to see their messages or additional applications every time while they are in class . The use of cell phones in class is important as part of the educational model based on and complemented by the use of virtual spaces, through various techniques such as e-learning, m-learning, u-learning, among others, where learning encompasses various dimensions (face-to-face, online and mixed). [11] as well as several authors, raise precisely the need to face today the fourth industrial revolution that is distinguished by the incorporation of new technologies that fuses the physical, digital and biological part, affecting all disciplines and fields of study .

The fact that a student searches in class, with the assistance of the teacher, information about an academic concept or field is very important, since the cell phone becomes a valuable tool for teaching support and homework solution, but instead of giving it that In this sense, students take advantage of any moment to distract their attention from the academic objective, so that reality eventually becomes failed exams, sanctions of all kinds, difficult to understand and study subjects, incomplete notes, unaccredited subjects, among other aspects.

Methodology

It is clear that Phubbing in the era of education 4.0 generates an impact on the satisfaction of student-teacher relationships, their school performance and the mental health of the students themselves. That is why, in the present study, it was decided to go beyond a theoretical analysis and thus be able to carry out a first approach with a concrete reality in students of the university level of a Technological University of central Mexico.

The objective was to describe the different uses of the cell phone in a school day by university students of a technological educational institution in central Mexico. The methodology used was descriptive and quantitative data collection. The population was composed of 120 students of the fifth and eighth semester of the Bachelor of Market Intelligence and Psychology who agreed to participate, obtaining a sample of 92 subjects, which was calculated using a formula for finite populations, using maximum variability, a level $95 \%$ confidence and $5 \%$ allowable error. The research hypotheses were 
$\mathrm{H}_{1}$ : At least $30 \%$ of the students participating in the study use the cell phone in class without the teacher's consent, that is, to attend matters personally.

$\mathrm{H}_{2}$ : There is a positive relationship between the dimensions of Phubbing and the turn in which the university students of the Technological University of central Mexico take their courses.

$\mathrm{H}_{3}$ : The type of student is strongly associated with each of the dimensions of Phubbing.

$\mathrm{H}_{4}$ : The dating / couple relationships that university students of the Technological University of central Mexico have, is positively associated with each of the dimensions of the Phubbing instrument.

The instrument used was a questionnaire designed by the authors of this research, based on those developed in other similar studies such as [1-3], among other authors. In a first section some general questions such as age, gender, type of student, school average, shift, among others, were grouped together. In a second section, items of various questions were raised on a Likert scale of 1 to 5 , where $1=$ never, $2=$ almost never, $3=$ sometimes, $4=$ almost always and $5=$ always, grouped into three dimensions or categories: A. Telephone use (10 questions), B. Telephone use problems (10 questions), C. Feeling guilty (5 questions). The reliability of the instrument was calculated, for which Cronbach's Alpha Coefficient was used, obtaining a value of 0.81 .

The initial questions of the socio-demographic type were used some of them only to make correlates with each of the three dimensions of the instrument to measure the Phubbing. Results

The results obtained in this first approach that was taken with the students who participated in the study, reflected the following general data:

Table 1

General characteristics of university students

\begin{tabular}{c}
\hline General characteristics Percentages and averages \\
Sample size = 92 cases \\
\hline Gender $82.1 \%$ are women ( 76 cases) \\
Age 20 to 22 years ( $53.6 \%-49$ cases) \\
Evening shift $64.3 \%$ ( 59 cases). \\
Student type $85 \%$ ( 78 cases) are regular students \\
Overall Average 8.2 \\
Number of subjects taken by $53.6 \%$ (akes 6 subjects. \\
Family relationships $90 \%$ ( 83 cases) have a good relationship. \\
Dating / partner relationships $42.9 \%$ ( 39 cases) have a good \\
relationship, $25 \%$ ( 23 cases) regular and the rest do not have a \\
boyfriend or girlfriend. \\
. Personal concerns $82 \%$ ( 76 cases) determined to feel some \\
type of concern, the family being the main one and of another \\
type. \\
Residence $53.6 \%$ (49 cases) does not live in the same place \\
where they study, so they have to travel.
\end{tabular}

Source: Own elaboration based on the results of the investigation

Table 1 shows the general data obtained from the applied survey, where the majority is women, whose ages fluctuate between 20 and 22 years and three-fourths study in the afternoon. It is striking that as the majority of the female sex, one might think that they are the ones that most tend by their nature to establish active telephone conversations. Also the turn could favor the greater use of the cell phone, since it is more common that in the afternoon there is greater availability of people to establish communication with their peers. The number of regular students in principle is high, although perhaps in future research, the failed subjects or extraordinary exams presented could be considered. Finally, the percentage of concern is high, which could be associated with the need to communicate frequently to somehow dissipate your concerns. This is in principle an overview of some socio-demographic variables, which will allow us to have a first approach and reflection of the data.

Next, a series of descriptive statistical data, based on the central tendency measures, is presented in Table 2 to break down some other important analyzes related to the three dimensions of the Phubbing instrument.

Table 2

Measures of central tendency of Phubbing in university students

\begin{tabular}{lccc}
\hline \multirow{2}{*}{$\begin{array}{c}\text { Descriptive } \\
\text { statistics }\end{array}$} & \multicolumn{3}{c}{ Phubbing Dimensions } \\
\cline { 2 - 4 } & $\begin{array}{c}\text { Using the } \\
\text { phone }\end{array}$ & $\begin{array}{c}\text { Telephone } \\
\text { use problems }\end{array}$ & $\begin{array}{c}\text { Guilty } \\
\text { feeling }\end{array}$ \\
\hline Half & 3.20 & 1.97 & 1.94 \\
Median & 3.15 & 1.80 & 1.60 \\
Mode & 2.88 & 1.40 & 1.40 \\
Standard & 1.01 & 1.08 & 1.10 \\
deviation & & &
\end{tabular}

Source: Own elaboration based on the results of the investigation

It can be seen that the highest average scores were obtained in the dimension corresponding to the use of the telephone with 3.20 , while the other two dimensions, problems of telephone use and feeling of guilt, were 1.97 and 1.94, respectively. This means that the frequency with which cell phones are used by university students is between the option sometimes and almost always, that is, if we consider that in the Likert scale option 1 is worth $0 \%$ and 5 is $100 \%$, then the values obtained would range between 50 and $75 \%$. With this the $\mathrm{H}_{1}$ hypothesis: At least $30 \%$ of the students participating in the study use the cell phone in class, without the teacher's consent, that is, to attend matters personally, it is accepted. Table 3

Average Phubbing scores with the turn

\begin{tabular}{lcccc|}
\hline $\begin{array}{l}\text { Phubbing dimensions/ } \\
\text { turn }\end{array}$ & Median & N & Test F & p \\
\hline Using the phone & 3.3389 & 59 & & \\
- Evening & 2.9400 & 33 & & \\
- Mixed & & & 0.171 & 0.822 \\
Using the phone & 2.0000 & 59 & & \\
- Evening & 1.9300 & 33 & & \\
- Mixed & & & 2.210 & 0.420 \\
$\quad$ Guilty feeling & & & \\
\hline
\end{tabular}




\begin{tabular}{lllll|}
\hline $\begin{array}{l}\text { Phubbing dimensions/ } \\
\text { turn }\end{array}$ & Median & $\mathbf{N}$ & Test F & $\mathbf{p}$ \\
\hline • Evening & 2.0333 & 59 & \\
- Mixed & 1.7600 & 33 & & \\
\hline
\end{tabular}

Source: Own elaboration based on the results of the investigation

Table 3 shows that the highestaverage scores correspond to the telephone use dimension (mean = 3.3389), with a significance level of 0.020 , which can be interpreted as a positive relationship with the evening shift students are taking. University students However, with the dimensions of telephone use problems and feelings of guilt, there is no positive correlation. That is why the hypothesis established $\mathrm{H}_{2}$ : There is a positive relationship between the dimensions of Phubbing and the turn in which the university students of the Technological University of central Mexico take their courses, it is partially accepted, that is, only with the first dimension of the Phubbing instrument used.

In table 4, the data derived from the correlates obtained between the three dimensions of Phubbing and the type of student are located. The highest average scores correspond to the telephone use dimension (mean = 3.2074), with a significance level of 0.010 , and the second dimension related to telephone use problems yields average data $=1.9889$ and $p=0.027$, while The third dimension that refers to feeling guilty reflex is not associated. All this means that according to the hypothesis: $\mathrm{H}_{3}$ : The type of student is strongly associated with each of the dimensions of Phubbing, it is partially accepted, since the variable type of student is strongly associated with two of the three dimensions of Phubbing. Table 4

Average Phubbing scores with the type of student

\begin{tabular}{llllc}
\hline $\begin{array}{c}\text { Phubbing dimensions / } \\
\text { student type }\end{array}$ & Median & $\mathbf{N}$ & Test F & $\mathbf{p}$ \\
\hline $\begin{array}{l}\text { Using the phone } \\
\text { •Regular }\end{array}$ & 3.2074 & 69 & 1.471 & 0.010 \\
$\quad$ - irregular & 2.9000 & 23 & & \\
$\begin{array}{l}\text { Telephone use problems } \\
\text { •Regular }\end{array}$ & 1.9889 & 69 & 0.795 & 0.027 \\
- Irregular & 1.6000 & 23 & & \\
Guilty feeling & & & 0.197 & 0.940 \\
$\quad$ Regular & 1.9333 & 69 & & \\
$\quad$ - Irregular & 2.0000 & 23 & & \\
\hline
\end{tabular}

Source: Own elaboration based on the results of the investigation

Finally, in Table 5, the dimensions of Phubbing were correlated with the variable called dating / couple relationships that university students who participated in the study may or may nothave. The results show that there is a positive association between telephone use (mean = 3.2750 and $p=0.030$ ), telephone use problems (mean $=$ 2.1833 and $p=0.042$ ) and guilt $($ mean $=2.0833$ and $p=$ 0.001 ). The $\mathrm{H}_{4}$ hypothesis: Relationships between couples and university students of the Technological University of central Mexico, is positively associated with each of the dimensions of the Phubbing instrument, is accepted.
Table 5

Average scores of Phubbing with dating relationships

\begin{tabular}{|c|c|c|c|c|}
\hline $\begin{array}{l}\text { Dimensions of the } \\
\text { Phubbing / dating } \\
\text { relationships / partner }\end{array}$ & Median & $\mathbf{N}$ & Test $\mathbf{F}$ & $p$ \\
\hline $\begin{aligned} \text { Using the phone } \\
-\quad \text { Good } \\
-\quad \text { Regular } \\
-\quad \text { Does not have a } \\
\text { boyfriend } \\
\text { girlfriend }\end{aligned}$ & $\begin{array}{l}3.2750 \\
2.8429 \\
3.3667\end{array}$ & $\begin{array}{l}39 \\
23 \\
30\end{array}$ & 3.619 & 0.030 \\
\hline $\begin{array}{l}\text { Telephone use problems } \\
\text { - Good } \\
\text { - } \text { Regular } \\
\text { Does not have a } \\
\text { boyfriend } \\
\text { girlfriend }\end{array}$ & $\begin{array}{l}2.1833 \\
1.5429 \\
2.0333\end{array}$ & $\begin{array}{l}39 \\
23 \\
30\end{array}$ & 1.665 & 0.042 \\
\hline $\begin{array}{ll}\text { Guilty feeling } \\
\text { - } & \text { Good } \\
\text { - } & \text { Regular } \\
& \text { Does not have a } \\
& \text { boyfriend } \\
& \text { girlf riend }\end{array}$ & $\begin{array}{l}2.0833 \\
1.6000 \\
2.0000\end{array}$ & $\begin{array}{l}39 \\
23 \\
30\end{array}$ & 0.757 & 0.001 \\
\hline
\end{tabular}

Source: Own elaboration based on the results of the investigation

Discussion of the findings obtained

The use of the cell phone in class is essential today for a university student, especially as a learning tool for the search of information, operation of platforms and specialized software, social networks, among others, but all of them focused on enhancing their knowledge in the classroom and under the supervision of the teacher. [2] states that there is a relationship between the use of mobile telephony and psychological well-being, that is, it can be interpreted that students who are constantly using their cell phone at all hours, including the classroom, can present sensations derived from aspects associated with their health, relationships with people, academic status, distraction and leisure, among others, that is, the effect can produce a positive or negative psychological wellbeing. The results obtained reflect that there is somehow an association between the use of the mobile telephone device with some present or past situational aspects of the university student, such as being a regular student or not, having had some problems in school or family, as well as neck pain, hands, tired vision, among other aspects. A recent study applied to professors of an American university [12] revealed the benefits that the use of technology brings and how important it is for students of this educational period called 4.0 to have permanent access to information and data that allow stimulate their intellectand skills, but also, the fact that mobile cell phone devices cause constantinterruptions and tension, that is, it seems that they become obstacles or switches that block teaching work. The majority of teachers surveyed, said that smartphones have a negative impact 
on classes, which is consistent with some findings obtained in this research, since more than $50 \%$ of students said they frequently use the cell phone during class for personal matters.

In future studies, some variables that require a longitudinal approach such as the shift, general average, study habits, gender, among others, of university students should be analyzed in depth, as they may become facilitators of excessive and inappropriate use of the cell phone in the classroom, as well as in other social settings.

\section{Conclusions}

It is important to recognize that Phubbing is a phenomenon that interferes with communication in the classroom and affects the university student in a personal way, in their psychological well-being and brings consequences to health and social relationships, so strategies should be sought for your attention and use responsibly.

Education 4.0 brings with it new educational models based mainly on the use of modern technology, however we must recognize the social reality that is currently lived with students of all educational levels, butabove all, in the university, in order to try challenge it, but not prohibiting its use, but rather that teachers together with the directors of schools and universities, establish control rules for the proper use of the cell phone and various electronic devices in class and thus collaborate with psychological well-being of university students, since as already stated, the solution is not to prohibit its use, but rather to use it responsibly.
[5] Hertlein, K. M., \& Blumer, M. L. (2014). The Couple and Family Technology Framework: Intimate Relationships in a Digital Age. Recovered from https://www.routledge.com/The-Couple-and-FamilyTechnology-Framework-Intimate-Relationships-in-a/HertleinBlumer/p/book/9780415641548

[6] González, J., Hernández, I., Martínez, R., Matos, J., Galindo, M. \& García, S. (2017). Technology interference in relationships and their impact on the mental health of Puerto Rican women. Puerto Rican Journal of Psychology, 29 (1), 56-71. Recovered from https://dialnet.unirioja.es/descarga/articulo/6496521.pdf

[7] Esparza, D. (2016). Communicated or connected? Recovered from https://es.aleteia.org/2016/09/26/comunicados-o-conectados/

[8] Gómez, J. (2013). Phubbing, another threat against interpersonal and labor relations. Recovered from https://www.merca20.com/elphubbing-otra-amenaza-contra-las-relaciones-interpersonales-ylaborales/

[9] Barrios, D., Bejar, V. \& Cauchos, V. (2017). Excessive use of Smartphones / cell phones: Phubbing and Nomophobia. Chilean Journal of Neuropsychiatry, 55 (3), 205-206. Recovered from https://scielo.conicyt.cl/pdf/rchnp/v55n3/0034-7388-rchnp-55-030205.pdf

[10] Felix, V., Mena, L., Ostos, R. and Acosta, M. (2017). Nomophobia as a Harmful Factor for Study Habits. Journal of Philosophy and Every day, $\quad 3 \quad$ (6), 23-29. Recovered from https://www.researchgate.net/publication/323933302_Nomofobia_com o_factor_nocivo_para_los_habitos_de_estudio

[11] Shawab, K. (2016). The Fourth Industrial Revolution. Kindle Edition Recovered from http://www3.weforum.org/docs/Media/KSC_4IR.pdf

[12] Guijosa, C. (2018). Smartphones are a distraction in the classroom, according to survey. Recovered from https://observatorio.tec.mx/edunews/los-smartphones-son-una-distraccion-en-el-salon-de-cla se

\section{References}

[1] Cisneros, L. \& Robles, S. What do university students use the cell phone in the classroom for? National Congress of Educational Research (COMIE). Congress held in San Luis Potosí, Mexico. http://www.adinarosario.com/fotos/biblioteca/adicc10g.pdf

[2] Capilla, E. \& Cubo, S. (2017). Phubbing Connected to the network and disconnected from reality. An analysis in relation to psychological wellbeing. Media and Education Magazine, 1 (50), 173-185. Recovered from http://www.redalyc.org/pdf/368/36849882012.pdf

[3] Villafuerte, C. \& Vera, M. (2019). Phubbing and gender in an academic sector in Quito: Use, abuse and interference of technology. Convergence Magazine, 1 (79), 1-19. doi: doi.org/ 10.29101 / crcs. v0i79.9156

[4] Vargas, I., Fernández, M. \& Bauza, B. (2016). Pedagogical communication and its influence on the process of teaching Spanish language learning: main problems in students of the primary education career in Las Tunas (Cuba). GeoGraphos Magazine, 7 (86), 132-146. Recovered from https://web.ua.es/es/revista-geographosgiecrya 1/documentos/idalmis-varga s.pdf 